\title{
INTERNAL AFFAIRS OF UNIONS: GOVERNMENT CONTROL OR SELF-REGULATION?
}

\author{
MORRIS D. Forkosch*
}

W HULE DISCUSSIONS concerning the activities of labor unions in relation to management and to government are numerous, comparatively little has been written about their internal affairs-their organization, their functioning, their relations to their members, and the methods by which internal discipline and the rights of members are enforced. In the past two centuries labor trends have reflected primarily the constant struggle for labor's betterment; it has been only comparatively recently that the relation of unions to their constituents has become part of the over-all labor picture and that a separate philosophy has been developed. ${ }^{x}$

It is not too daring to predict that within our lifetime the American trade union will assume that degree of stability which has characterized the English scene for many decades and will arrive at the point where future gains must be measured primarily in terms of productivity. This labor millennium, if it be such, will bring responsibilities commensurate with the power possessed, ${ }^{2}$ and it appears most probable that the one important area which thereupon must widen both for labor and for governmental discussion will be that which involves the relation of member to member, of member to union, and of union to union.

* Professor of Law, Brooklyn Law School.

The conflicting approaches are best illustrated in Anderson, Introduction to Brown, National Labor Policy 7 (I950).

$=$ The most important and "ultimate" of such power possibilities is, under our capitalistic system, the joint management of industry or, at the very least, board membership and a share in the decisions involving production policy, prices, employment and discharge. That such a goal is not overlooked today is seen in numerous efforts by some labor leaders and organizations either to join management directly, through stock purchases and voting, or through collective bargaining procedures and processes. The International Ladies Garment Workers Union, for example, has great control over small-shop physical production. Dr. William Oomberg, head of the union's division of production efficiency, has the task of suggesting to employers methods of increasing production and efficiency, thereby resulting in greater income for increased profit and wage distribution. Reference should be made to the German situation where the Ruhr steel and iron industries were confronted by the West German Metal Workers' Union demands, through a strike threat, for "co-determination." Chancellor Adenauer was reported as having endorsed, in principle, a law that would give the workers the right to bargain with employers as to matters involving production, sales, and purchasing policies as well as on wages and hours. Consult N.Y. Times, p. 6, col. 4 (Jan. 5th, I95I) and \& I, p. 23, col. r (Jan. 7th, I95r). 
The experience abroad discloses, however, that this labor maturity was not alone the result of passing years, but was also a consequence of numerous legislative and judicial internal restrictions. ${ }^{3}$ It may therefore be profitable to examine the trend of legislative and judicial interference with the internal functionings of trade unions in this country and to determine the motivations and objectives of this interference.

During the decade commencing in 1937 numerous restrictions and requirements involving the internal affairs of unions were enacted, covering a multiplicity of topics. The North Dakota Union Regulation Act of $1947,{ }^{4}$ as an example of a statute which was narrow in scope, required merely that unions file annually the names, addresses, and salaries of their officers, union aims and objectives, the scale of dues, and the amount of money collected.

The Delaware Act ${ }^{5}$ of the same year represented the opposite extreme. In addition to the usual informational requirements, there must be filed annually reports concerning: union initiation fees, dues, and assessments levied in the preceding twelve months; union limitations on membership; the number of paid-up members; election details, including the number of votes for and against each candidate; the date of the last financial statement furnished members, copies of which must be filed semi-annually. Copies of all working agreements with employers must similarly be filed. These provisions actually required unions to do no more than publicize what they already do on their own initiative. However, the Delaware law also required that union constitutions provide for democratic methods of government and rendered void all provisions concerning terms and conditions of work, hours, and labor-saving devices. Increases in fees or dues, and election of officers, ${ }^{6}$ require a majority vote; no initiation fee is to be

${ }^{3}$ The English Trade Disputes and Trade Unions Act, I7 \& I8 Geo. V, c. 22, §4 (r927), for example, forbade unions from requiring any member to contribute to a union political fund without his consent. This act may have been intended to weaken union treasuries and render impotent any political labor influence, but coincidentally therewith the internal functioning of unions was affected. There is an American counterpart to this restriction, Labor Management Relations Act of $x_{947} \S 304,6$ I Stat. $x_{59}$ (1947), I8 U.S.C.A. § 610 (1950), which makes it unlawful for any labor organization to make a contribution or expenditure in connection with any "federal election or state primary or convention or caucus to select a federal candidate." On the other hand, this legislation involves external union contributions, whereas the English statute prohibited compulsory internal union assessments for political purposes.

4 N.D.L. (1947) c. 242 , § 3. For information on the state statutes here discussed, see Cohen, State Labor Legislation, $1937-1947$ (1948).

5 Del. L. (I947) c. I96, $\$$ I8. Also, hiring halls are outlawed, as well as coercion of employers to employ recommended or approved individuals, or any other method of interference with the employer's right to choose his own employees. This Act, however, has been repealed by I950 legislature.

${ }^{6}$ Ibid., $\S 21$. Aliens, Communists, and persons convicted of a felony are barred from holding office. 
over twenty-five dollars; elections must be by secret ballot after at least fifteen days' notice to all members; no such election is to be valid if influenced by coercion, or intimidation, and the results must be tabulated by an impartial outsider. As to strikes, notice of the taking of a strike vote must be given to all members, and an employer affected thereby "must be given the privilege of attending and stating orally the proposals made by him to the union." The Taft-Hartley Act, while not as severe, is nevertheless as sweeping."

It may be queried why this sudden influx of government regulation in the internal affairs of unions has suddenly assumed these awesome proportions. Aside from particular instances of official corruption, which

7 Tbid., $\S \mathrm{r} 8$. In addition, no suspension or expulsion is lawful except for good cause and after a fair and public hearing.

${ }^{8}$ Cohen, op. cit. supra note 4 , at $3^{\circ}$. Mention is also made of other state laws, including the Fair Employment Practice Acts in a few jurisdictions, which outlaw such union practices as discriminating against anyone because of race, color, religious and national origin or ancestry. Ibid., at $3 \mathrm{I}-32$. While these purposes are extremely laudable and unquestionably "acceptable," it is the method employed, i.e., legal coercion, with which our examination is concerned. Likewise do we eschew any question of wisdom or desire, concentrating again merely upon the state's act per se. That unions voluntarily pledge, in collective bargaining agreements, not to discriminate against a nonunion worker or applicant because of race, creed, color, sex, marital status, national origin, or political beliefs, and that they thereby go beyond statutory requirements, is borne out in Abraham Weiss's study of collective bargaining provisions which details "Union Functions, Rights, and Responsibilities," Bureau of Labor Statistics, Bull. go8-2, 5I-54 (1949).

9 Labor Management Relations Act of $1947, \S 9(\mathrm{~h}), 6 \mathrm{r}$ Stat. $x_{46}$ (I947), 29 U.S.C.A. $\S$ I59(h) (Supp., I950), provides for filing of non-Communist affidavits, which is a regulation of union-desired conduct in that it restricts the field of permissible choices. Constitutionality was upheld in American Communications Ass'n v. Douds, 339 U.S. 382 (I950). The "good" or "bad" aspects of this requirement are of no present concern since we here investigate limitations as such. Parenthetically, it may be pointed out that practically all American labor unions detest communist infiltrators even more than many a governmental official, and the experiences of the past two years have demonstrated this forcefully. Insofar as internal union charges against union officials or members are concerned, the Ford Local 600 of the U.A.W., CIO, recently tried five local officials on charges of violation of the International constitution which barred Communists from office. N.Y. Times, p. 77, col. 3 (Oct. 8, x950). During r95० the CIO expelled eleven Unions whose leadership was accused of communist activities and party-line-following, and which were considered detrimental to the CIO policies; prior to expulsion, charges were preferred, a hearing or trial was held, and due process was accorded. N.Y. Times, p. 7 I, col. 4 (Jan. 2, r95I).

Section $9(f)(A)$ requires the filing of union names and addresses, the names, titles, compensation and allowances of the three principal officers and of any others whose aggregate income exceeds $\$ 5,000$ per annum; the manner of selection of such individuals; initiation fees; amount of regular dues; detailed statements of constitutional and by-law provisions regarding membership qualifications, elections, meetings, assessments, fines, contract ratification, authorizations for strikes, disbursements, audits, expulsions and grounds therefor. Sections 9 (f)(B) (2) and $9(\mathrm{~g})$ require, however, that financial reports be given not alone to the government but to union members as well, and the National Labor Relations Board requires proof thereof before its facilities may be invoked. The requirements of $g(f)$ and $g(g)$ have been upheld as constitutional in National Maritime Union v. Herzog, 78 F. Supp. 146 (D.C. r948), aff'd 334 U.S. 854 (I948). It is this type of affirmative union action-legislatively imposed-which is of present concern. 
might perhaps have easily been overcome by existing criminal statutes, the very nature of the autonomous international union ${ }^{\text {ro }}$ has made it suspect, and therefore has required that it be subject to the law. The fundamental question is raised whether the mere existence of power, regardless of the nature of its being or the conditions of its exercise, does not deprive the possessor of absolute immunity (constitutional or otherwise) to which it might ordinarily be entitled..$^{22}$

ro The hierarchy of labor groupings is not presently important, and it is sufficient to note here merely the autonomous nature of the international union and its greater power over the local. Cf. Brooks, When Labor Organizes (I937) passim, $25^{2}$ et seq., wherein the scene up to 1937 is portrayed and the evolution of the international's power is displayed. The conclusions given in the last paragraphs of this article, which seemingly relate solely to the individual unionist engaged in a dispute with his local union, are nevertheless relevant to a unioninternational or international-federation controversy. See N.Y. Times, $\$ \mathrm{x}$, p. 35, col. 5 (Dec. 2x, I950) which lists the International Ladies Garment Workers Union charges against the head of the New York City Central Trades and Labor Council. A committee was appointed but it is questionable whether the AFL has much power to do aught but investigate the facts.

It may now be noted that any discusion hereinafter concerning a "contract" between local union and local member is not to be deemed to omit consideration of the contract between the international and the local, for the charter issued to the latter is a contract which binds the local's members as well, and the international charter may therefore be termed the basic contract upon which the local's subsidiary contract with the members must be built and which serves to define, limit, and otherwise control all rights or privileges emanating therefrom.

II "Subject to the law" should be read here as "subject to some aspects of particular laws," for general enactments covering general conduct will bear most heavily upon certain groups. For example, the basic purpose of the Sherman Act of 1890,26 Stat. 209 (I89o), I5 U.S.C.A. $\$$ I et seq. (I950), is generally conceded to have been control of business practices overstepping permissible borders, but the generality and vagueness of the law was so construed as to bring labor within its ken. The eventual result was the Norris-LaGuardia Anti-Injunction Act of r932, 47 Stat. 70 (r932), 29 U.S.C.A. $\$ \S ~ r O I-I_{5}$ (I950) and the changeover in judicial thinking. See Forkosch, Equity Versus Taft-Hartley Injunctions, 24 Temp. L.Q. 277 (I95I), for a presentation of the historical basis, development, and present condition of labor injunctions.

12 See note I7 infra. Reference is also made to the Durham incident in England where the Durham County Council voted to impose closed-shop conditions upon all its 15,000 employees, despite the Labour Party (national) Government's disapproval, and thereby touched off a controversy which rocked the Party. N.Y. Times, p. I8, col. 3 (Nov. 29, r950).

See the opinion of Justice Douglas, dissenting, in United States v. Columbia Steel Co., 334 U.S. 495, 536 (1948), with which Justices Black, Murphy, and Rutledge concurred: "Power that controls the economy should be in the hands of elected representatives of the people, not in the hands of an industrial oligarchy. Industrial power should be decentralized. It should be scattered into many hands so that the fortunes of the people will not be dependent on the whim or caprice, the political prejudices, the emotional stability of a few selfappointed men. The fact that they are not vicious men but respectable and social minded is irrelevant. That is the philosophy and the command of the Sherman Act. It is founded on a theory of hostility to the concentration in private hands of power so great that only a government of the people should have it."

Forkosch, op. cit. supra note $r x$, discusses the legislative and decisional history of the three interlacing anti-trust statutes, with the Supreme Court's final about-face on legislative grounds. Today union action for its self-betterment is safe-guarded from anti-trust prosecution where such activity is not part of any entrepreneurial scheme or collaboration. See also CIO Department of Education and Research, "Labor Monopoly"-A Phony Issue, II Economic Outlook 25 (I950), for an excellent discussion of the reasons why labor organizations feel they are not monopolies subject to the anti-trust laws. The point of such discussion lies in its propaganda offset to business efforts to bring labor under such laws in the future. 
Are unions today so powerful that the public interest requires immediate checks regardless of objective abuses? ${ }^{\times 3} \mathrm{Or}$ is it merely the rapidity of their growth in the past decade and a half, since the Wagner Act's passage, that makes them loom so large to our unaccustomed eyes? Most likely it is this latter aspect which has been the reason for recent restrictions, for unions today are still numerically a working minority and the recent r950 elections have cast doubt on their ability to "deliver" politically in all instances. ${ }^{14}$ The fears engendered during the Wagner era, ${ }^{15}$ resulting in the stringent post-war state and federal statutory restrictions, ${ }^{16}$ may well dissipate themselves, although their memory will linger. It is still "in the cards" that labor will in the not-too-distant future "find

${ }^{3}$ In passing upon the constitutionality of a state prohibition of union financial contributions to political parties or to persons running for political office, Ann. Civ. Stat. (Vernon, 1925) art. 5I54a, $\$ 4(\mathrm{~b})$, the Court of Civil Appeals of Texas upheld such provision, stating that such "laws are designed to prevent [elected officials from] becoming unduly amenable to, or subject to undue control or influence by, any particular group when the interests of such group affect the public interest." American Federation of Labor v. Mann, I88 S.W. 2d 276, 283 (Tex. Civ. App., 1945).

${ }^{14}$ This was the popular and immediate reaction to the $195^{\circ}$ election returns. A more analytical approach, reaching contrary conclusions, is found in Hollander, Labor Didn't Lose the Elections, 34 New Leader I8 (195I), where it is stated: "Labor has never contended that it could elect candidates by its own efforts alone. We have always made the point that we must work together with all other groups which have the same interest in good government that we have. ..." Ibid., at Ig.

${ }_{15}$ For a general approach, setting forth one person's reactions to these alleged "public fears," see Arnold, The Bottlenecks of Business (I940), c. XI, entitled "Labor-Restraints of Trade Among the Underdogs." For one of the most comprehensive reports concerning particular fears during this period, reference is made to the American Civil Liberties Union's I94I Committee on Trade Union Democracy which promulgated one such study in I943 under the title "Democracy in Trade Unions-A Survey, With a Program of Action." The Committee felt that "[t]he increasing responsibilities placed on trade unions by governmental protection of their democratic rights demand that they in turn accept the responsibility for the democratic conduct of their own affairs. An autocratic union, run without the full participation of its membership, cannot morally claim democratic rights in dealings with employers through the intervention of public agencies." Ibid., at 7.

${ }^{16}$ Brown, op. cit. supra note I, surveys the Taft-Hartley Act after three years and mentions five reasons for that Act's passage. The first and fifth involve "union actions which roused public fear and resentment" and "the legislative process" culminating in the 1947 Act. The author concludes: "Abuses in the internal affairs of a minority of unions also gave the labor movement a black eye. There was ground for criticism for excessive fees charged under some closed-shop contracts, laxness in the finances of occasional unions, restrictions on membership, and arbitrary expulsions." Ibid., at I5. As to the legislative process, the author points to state enactments preceding the passage of the Act, beginning with restrictive state legislation in I943 and culminating in "the flood of anti-closed-shop and other restrictions in I947. The major part of this legislation came from the South and Southwest, and from the largely agricultural states of the Midwest and Far West. But it was cited as evidence that 'the public' demanded restraints on union abuses and it had its influence in bringing federal action," ibid., at 6, citing Millis \& Brown, From the Wagner Act to Taft-Hartley $3^{16-22}$ (r95o). For an appraisal of this volume see this writer's review in I7 Brooklyn L. Rev. I63 (I950). For an early comparative study of the American Federation of Labor's and the Chamber of Commerce's programs and attempted influencing of legislation, see Childs, Labor and Capital in National Politics (I930). 
itself" both with respect to power and to maturity and that wise leadership will accept the responsibilities which such power entails.

Insofar as power is here involved, let us examine the position of an individual union member who is involved in an internal schism and is catapulted into a fight for his economic life. Since in a closed or union shop an employer will ordinarily be reluctant to intervene in an intraunion quarrel, ${ }^{\mathrm{I}}$ any labor "boss" can apparently wield despotic powers which affect individuals, families, and often entire communities. Although the modern labor leader bears but little resemblance to his popular stereotype of the I930's and I940's, ${ }^{18}$ his power over the destinies of individual members may still be extensive. What limitations, both internal and ex-

${ }^{17}$ For example, assume a worker desired to join a union for no reason other than to be a member of a group. Can he legally force himself in by obtaining court relief compelling the union to admit him? The answer is obviously no, and cases are unnecessary, for otherwise all social groups would be invaded and disbanded. But assume the worker is faced with some form of the closed shop, thereby rendering it impossible for him to obtain permanent work unless he is a union member-and the union refuses to admit him. A long series of cases say no, with the pattern being set in Mayer v. Journeymen Stone-Cutters' Ass'n, 47 N.J. Eq. 519, 20 Atl. 492 (I890). See also Simons v. Berry, 210 App. Div. 90, 205 N.Y. Supp. 442 (rst Dep't, I924); Miller v. Ruehl, $x 66$ N.Y. Misc. 479, 48I, 2 N.Y.S. 2d 394, 395 (S. Ct., I938); Consult Chafee, The Internal Affairs of Associations Not for Profit, 43 Harv. L. Rev. 993 (I930); Mintz, Trade Union Abuses, 6 St. John's L. Rev. 272 (I932).

Does this mean that such worker has no recourse? Although the I8 $9 \circ$ New Jersey Mayer case, supra, left the work-seeking applicant without remedy where the union arbitrarily closed its doors to future membership during one year, the case of Wilson v. Newspaper Deliverer's Union, I23 N.J. Eq. 347, I97 Atl. 720 (I938), saw the same court holding now that it was against public policy for a closed-shop contract to force out of his twelve-year employment an individual worker who was refused membership because the union roster was full and many of its members were unemployed. Query: Would a one-year closing have been upheld on the Mayer decision? The factual difference rests upon legal-, mental-, and will-coercion, which caused the court to denounce these "baldly selfish" policies even though admitting "that the monopolistic tendencies or purposes or contracts of such unions are not contrary to the policy of the state." However, continued the court, "[a] monopoly raises duties which may be enforced against the possessors of the monopoly.... [T]he holders of the monopoly must not exercise their power in an arbitrary, unreasonable manner so as to bring injury to others. The nature of the monopoly determines the nature of the duty. . . A union may restrict its membership at pleasure; it may, under certain conditions, lawfully contract with employers that all work shall be given to its members. But it cannot do both." Ibid., at $35^{\circ}$ and 722. Consult Forkosch, Secondary Boycotts Under the Taft-Hartley Law, I CCH Lab. L.J. xoog (I950).

See also recent state statutes prohibiting or regulating a closed shop, union shop, or varieties thereof, Cohen, op. cit. supra note 4 , at I3-I8, II5-I2I. See also, for federal legislation, Labor Management Relations Act of $x 947, \S 8(\mathrm{a})(3)$ ), 6I Stat. I40 (I947), 29 U.S.C.A. $\S 1_{5} 8(\mathrm{a})(3)$ (Supp., $x_{950}$ ), prohibiting the closed shop but permitting a union shop under certain conditions, not here required to be expanded upon. Other statutes, like the New York Civil Rights Law (McKinney, I950) $\$ \S 4 \mathrm{I}-43$, prohibiting union refusal of membership because of race, color, or creed, are not detailed.

${ }^{8}$ The late Sidney Hillman, of the Amalgamated Clothing Workers Union, David Dubinsky of the I.L.G.W.U., William Green, Philip Murray (and even John L. Lewis) are examples of labor leaders who have proved themselves contrary to the stereotyped notion of the "grasping monopolist." Consult Ginzberg, The Labor Leader (I948); Mills, The New Men of Power (I948). 
ternal, have been imposed on the abusive exercise of such power? It is with these restrictions that this paper is primarily concerned.

First and foremost in our examination are the restrictions imposed by the union itself in its constitution and by-laws, which are the union's fount of power and authority ${ }^{19}$ as well as the source of member's rights. ${ }^{20}$ These documents control all internal union affairs. ${ }^{2 x}$ Courts have generally permitted union interpretation ${ }^{22}$ and enforcement of their own constitutional provisions, ${ }^{23}$ even though the result may be to limit a member's freedom of action ${ }^{24}$ or his union constitutional rights. ${ }^{25}$

This does not, of course, mean that a union is a government within its borders, self-sufficient and answerable to no one. For over and above the union are the federal and state governments. Thus a union may not enact constitutional provisions contrary to express criminal or civil

\footnotetext{
19 See Nilan v. Colleran, 283 N.Y. 84,27 N.E. $2 d$ III (I940), as to the charter from an international; McFadden v. Murphy, I49 Mass. 341, 2 I N.E. 868 (I88g), regarding the constitution. We shall use "constitution" for both of these, as well as for the by-laws, unless the contrary is indicated.
}

${ }^{20}$ Pratt v. Rudisule, 249 App. Div. 305,292 N.Y. Supp. 68 (4th Dep't 1936). In expelling certain members in direct contravention of union constitutional procedural provisions, the union was compelled to reinstate and was held liable in damages for loss of earnings. Harris v. Nat'l Union of Marine Cooks \& Stewards, 221 P. 2 d I36 (Cal. App., I950).

${ }_{2 x}$ O'Keefe v. Local ${ }_{4} 6_{3}$ of United Ass'n of Plumbers, 277 N.Y. $300, x_{4}$ N.E. $2 d 77$ (I938); Opera on Tour v. Weber, $25^{8}$ App. Div. 516, 17 N.Y.S. 2d r44 (Ist Dep't, 1940), rev'd 285 N.Y. 348,34 N.E. $2 d$ 349 (194I). See also Pratt v. Rudisule, 249 App. Div. 305,292 N.Y. Supp. 68 (4th Dep't, 1936); Kaplan v. Elliot, 145 N.Y. Misc. 863, 26r N.Y. Supp. II2 (S. Ct., r932); Irwin v. Possehl, 443 N.Y. Misc. 855, 257 N.Y. Supp. 597 (S. Ct., I932); Bricklayers', Plasterers' \& Stonemasons' Union v. Bowen, 183 N.Y. Supp. 855 (S. Ct., I920); Tesoriero v. Miller, 274 App. Div. 670, 88 N.Y.S. $2 d 87$ (4th Dep't, I949).

${ }^{22}$ Since interpretation may easily become union legislation and thus result in an indirect enactment via non-constitutional means, courts will generally permit only union construction in good faith, through its regularly constituted tribunals, and not in contravention of public policy, to be final and binding on members. Pratt v. Rudisule, 249 App. Div. 305,292 N.Y. Supp. 68 (4th Dep't, 1936); Sullivan v. Barrows, 303 Mass. 197, 2I N.E. 2d 275 (1939); Heasley v. Operative Plasterers, etc., Ass'n, Local No. 3I, 324 Pa. 257, I88 Atl. 206 (I936).

, ${ }^{23}$ W. F. Construction Corp. v. Hanson, 250 App. Div. 727, 293 N.Y. Supp. I7o (2d Dep’t, 1937).

${ }^{24}$ As by preventing its members from joining other like types of association, Interborough Rapid Transit Co. v. Lavin, 247 N.Y. 65, Y59 N.E. $86_{3}$ (r928); or from seceding with a local's property, even though the vast majority is in favor, where a constitutional minority is adamant, Martin v. Smith, 286 Mass. 227, rgo N.E. II3 (r934); or from claiming lack of notice where he is suspended for nonpayment of dues, Sammel v. Myrup, I2 N.Y.S. 2d 2I7 (N.Y. Munic. Ct., r939).

${ }_{25}$ In Curatella v. Scida, Spec. Term Part 3 , N.Y.L.J. (March 24, r948), Justice Hammer denied a unionist's application of judicial reinstatement after having been duly tried and found guilty by the union's executive board, stating that "[ $t$ ]he proceedings having been regular, plaintiff is entitled to no relief. The court will not substitute its judgment for that of the executive board, nor will the court review the proceedings or reexamine the merits of the expulsion...." 
statutes, nor may it take action in contravention of such legislation. ${ }^{26}$ Aside from legislation imposing requirements as to the content of union constitutions, other statutory provisions exist which mold union action toward union members. On the national scene, Section $8(\mathrm{~b})(\mathrm{I})$ of the Taft-Hartley $\mathrm{Act}^{27}$ makes it an unfair union labor practice to restrain or coerce employees in their Section 7 rights but does "not impair the right of a labor organization to prescribe its own rules with respect to the acquisition or retention of membership therein...." Section $8(b)(2)^{28}$ forbids union coercion of an employer to cause him to discriminate against an employee to whom union membership "has been denied or terminated on some ground other than" non-payment of dues or initiation fees, thereby in effect limiting the preceding subdivision's "grant" or "re-iteration" of labor's long-held right to determine its own membership conditions. ${ }^{29}$ For when the union has a union shop, judicial review of expulsion is eventually accorded for all "ground[s] other than" nonpayment of dues or initiation fees. ${ }^{30}$ Likewise, under Section $8(b)(5),{ }^{3 x}$

${ }^{26}$ The latest Supreme Court pronouncements upon this subject of state policy are: Hughes v. Superior Court of Calif., 339 U.S. 460 (I950); International Brotherhood of Teamsters v. Hanke, 339 U.S. $47^{\circ}$ ( $\mathrm{r}_{95^{\circ}}$ ); and Building Service Employees v. Gazzam, 339 U.S. 532 (1950).

${ }^{27} 6 \mathrm{I}$ Stat. I4I (I947), 29 U.S.C.A. § I58(b)(I) (Supp., I950).

${ }^{8}$ 6r Stat. I4I (I947), 29 U.S.C.A. \& I58(b)(2) (Supp., I950).

29 For example, what of a union constitutional provision providing for the expulsion of a dual unionist? Say that Jones, a member of $X$ union which has a union shop agreement, becomes the guiding spirit of a rival union which is seeking to oust $X$ from Board certification. May X expel Jones and then request the employer to fire non-member Jones from its valid union shop contract? Or is this a violation of $8(\mathrm{~b})(2)$ ? Numerous NLRB cases hold that it is and refuse to permit such discharge, and the courts have upheld such interpretation.

30 In Pen \& Pencil Workers Union, 2 CCH Lab. L. Rep. ๆ xo,353 (r950), the NLRB has recently held a worker's refusal to pay two of three twenty-five dollar fines assessed against her by the union in 1947 to be insufficient to justify the union's actions causing her discharge, and has ordered the union to reimburse the employee for her loss of wages and to notify the company that it had no objection to her immediate reinstatement. Thus a member's failure to pay only the statutory "periodic dues" or "initiation fees" which $8(\mathrm{~b})(2)$ enumerates can be considered ground for discrimination, i.e., causing discharge, since "[t] he legislative history of the I947 amendments to the act fully supports the conclusion that fines generally were not intended to be encompassed within" such terms. Tbid., at n. 6. Member Murdock, in an October I2, I950 amendment, inserted footnote $5 \mathrm{~A}$ wherein he reserved judgment on the question whether $8(\mathrm{a})(3)$ and $8(\mathrm{~b})(2)$ require, or do not require, an employer "who actually effected the discriminatory discharge" to be an indispensable party respondent.

On January 6, I95I, the Board decided the case of Electric Auto-Lite Co., 2 CCH Lab. L. Rep. IIO,537, 92 N.L.R.B. No. I7I (I95I), which involved discharge of an employee because of his failure to pay a union "dues increase" of fifty cents a month, the Board finding it actually was a fine for failure to attend union meetings. A valid maintenance-of-membership contract was in existence, but insofar as it permitted and required discharges for loss of union membership where reasons other than "periodic dues and ... initiation fees" were involved, an $8(a)(3)$ and $8(b)(2)$ violation had occurred, with the former applying because the employer had "reasonable grounds for believing" the expulsion was for such "other" reasons. The union and employer were held "jointly and severally" liable for loss-of-pay reimbursement as well as reinstatement, etc. Chairman Herzog and Board Members Reynolds and Mirdock concurred, with Board Member Styles dissenting.

3x 6I Stat. I42 (1947), 29 U.S.C.A. \& I58(b)(5) (Supp., I950). 
which forbids labor organizations having a union shop contract under Section 8(a)(3) to require "excessive or discriminatory" initiation fees, eventual judicial review is found inherent in such statutory provisions, so that in these two subdivisions are found restrictions upon unions' internal functionings, as well as possible judicial review thereof. ${ }^{32}$ Section $\mathrm{I}_{4}(\mathrm{~b}),{ }^{33}$ however, must not be overlooked; although Section $8(\mathrm{a})(3)^{34}$ permits union shop contracts, ${ }^{35}$ Section $\mathrm{I}_{4}(\mathrm{~b})$ permits states to forbid and outlaw their execution or enforcement within their borders. Thus in states which have outlawed union shop agreements, Section $8(\mathrm{~b})(2)$ does not operate to deter unions from setting whatever membership qualifications they desire; in short, the Section becomes irrelevant in those states.

The local scene is a conglomerate statutory and decisional kaleidoscope which reflects extremes of black and white but with grays of varying shades predominating. For a statutory example, the 1943 Colorado Labor Peace $\mathrm{Act}^{36}$ required union incorporation and permitted any member to have recourse to the State commission or to the courts whenever he had a complaint "which involves his right to work, punishment, elections, dues,

${ }^{32}$ (a) Union conduct under 8(b)(2) may result in employee reinstatement and a back pay award. Consult note 28 supra.

(b) It is also an unfair labor practice under $8(\mathrm{a})(3)(\mathrm{B})$ for an employer to discriminate against an individual when he knows or has reasonable grounds for believing that a union violation under $8(\mathrm{~b})(2)$ has occurred. Authorities cited note 28 supra, especially the Murdock reservation in the Pen \& Pencil Workers case.

33 6I Stat. I5I (I947), 29 U.S.C.A. § I64(b) (Supp., I950).

34 6 I Stat. I40 (I947), 29 U.S.C.A. \& I58(a)(3) (Supp., r950).

35 Closed-shop agreements are forbidden, regardless of local desires, but since the Labor Management Relations Act operates outside of intrastate commerce, the local rules prevail where intrastate commerce is involved. A possible no-man's land appears to exist, however, in that the NLRB's recently-promulgated self-imposed rules for taking jurisdiction of labor cases eliminates matters of unimportance, NLRB Release R-342 (Oct. 6, 1950); but since these are admittedly in interstate commerce, are the states powerless to act thereon? Either the doctrine of Leisy v. Hardin, 135 U.S. roo ( 1890 ), or Cooley v. Board of Wardens of Port of Philadelphia, I 2 How. (U.S.) 299 (185 I) is applicable, assuming the Board does not, or cannot, agree with the local boards under Section ro(a) of the Act. Under the Leisy doctrine no state power to act exists; under the Cooley doctrine a possible state power exists provided national pre-emption has not occurred. Thus the Act must be interpreted as to whether or not Congress has granted power (which it undoubtedly has not, under the Leisy doctrine) or preempted it (which it seemingly has, under the Cooley doctrine) subject to Board agreement under Section Io(a). It is to be noted further that the Wagner Act made the Board jurisdiction "exclusive," whereas the amended Act permits cession of jurisdiction in unfair labor practices where interstate commerce is involved (save in certain fields) provided the state laws are not inconsistent with the federal Act's corresponding provisions. This last limitation is, of course, the limitation upon Board agreement and possible state action or inaction-and, if the latter, the source for the no-man's land previously mentioned. For a discussion of a possible no-man's land in secondary boycotts, consult Forkosch, NLRB's New Jurisdictional Rule on Secondary Boycotts, 2 CCH Lab. L.J. 247 (r95I).

${ }^{36}$ Upheld by the Supreme Court of Colorado in Denver Milk Producers v. International Brotherhood of Teamsters, II6 Colo. 389, I83 P. 2 d 529 (I947), appeal dismissed, 334 U.S. 809 (r948), except for the compulsory union incorporation provisions, Sections 20 and $2 \mathrm{I}$, previously denounced in AFL v. Reilly, Ir3 Colo. 9o, I55 P. 2 d I45 (I944). 
assessments, fees, or the malfeasance of any officer...." ${ }_{37}$ Maintenance of the status quo ante was obtainable by providing that no union punishment was enforceable unless ten days' prior notice was given the State Commission and the member; the latter was given such period in which to lodge a complaint whereupon the punishment was stayed until the commission hearing and determination. ${ }^{38}$ Directly or indirectly an eventual judicial review was here permitted, ${ }^{39}$ so that a union now had to justify any punishment both to the commission and to the courts.

This type of legislation is not, generally speaking, found in such assembled form in the other states where more particularized laws and sections become of interest. Massachusetts, for instance, permits but does not compel union incorporation if certain provisions relative to expulsion, among others, are incorporated in the by-laws; these provisions must provide that no member may be expelled either by a vote of less than a majority of all members or by less than three-quarters of all members voting..$^{40} \mathrm{New}$ York does not permit a labor organization, because of "race, creed, color or national origin," to "deny a person or persons membership in its organization" or to "deny any of its [said] members ... equal treatment" or to discriminate in any way against them, and empowers courts to enforce this Civil Rights Law whenever the Industrial Commissioner makes application therefor. ${ }^{4 \mathrm{I}}$ Nowhere, however, is there a comprehensive code framed for the exact purpose of regulating all particular aspects of permissible union punishment, including suspension or expulsion, of its members. The subject apparently has been left to judicial evolution plus

37 § $20(\mathrm{f})$ II. Although Sections 20 and 2 I were declared unconstitutional, still such union limitations can be easily re-enacted and used against unions per se, even though unavailable as against incorporated unions.

${ }^{38} \S 20(f)$, T2. Under Section $8(2)$ a procedure for deciding unfair labor practices is outlined. This procedure is followed for the complaints regarding expulsion or other punishment under Section $20(\mathrm{f})$.

39 Under Section $8(8)$ an aggrieved party to a hearing might file a petition for judicial review within thirty days after the Commission's order, and under Section 8(ro) such petition "shall, unless otherwise specifically ordered by the court, operate as a stay of the Commission's order."

${ }^{40}$ Mass. Gen. Laws (Michie, I933) c. $180, \$ \S$ I6, I7, 18.

${ }_{41}$ New York Civil Rights Law (McKinney, r950) $\$ \$ 43-45$, quoting from N.Y. Executive Law, N.Y.L. (1945) c. I18, art. I2, § 43, known as the "Law Against Discrimination," is a general law against discrimination in the field of private employment and in $\S$ I33 states that "'a]ny complainant, respondent, or other person aggrieved ... and the Commission (likewise) may obtain" judicial review or enforcement in the state courts. Several other states have similar provisions, as Connecticut, Massachusetts, New Jersey, New Mexico, Oregon, Rhode Island, and Washington, while several others are studying the question, as Illinois, Indiana, Kansas, Nebraska, and Wisconsin. 
legislative revolution, and the general legal principles pertaining to voluntary associations have been permitted to control.

Aside from such statutes, however, a union member found guilty of certain charges according to union constitutional procedure may still have recourse to outside agencies. The doctrine of "exhaustion of remedies" requires all internal union possibilities to be availed of prior to external appeal..$^{42}$ Assuming, however, that all internal union remedies have been exhausted, but to no avail, can the member who has been expelled or punished do anything else? If his legal remedies are confined to internal appeals only, how can he seek external judicial review to vacate or modify union action? Unless a governmentally-granted (state or federal) right is involved there is no such availability of judicial review, for there is no "labor dispute" involved, ${ }^{43}$ and if the Fifth or Fourteenth Amendment due process clauses may not be invoked, it would appear as if the unionist is without remedy.

Once a worker is admitted to a union, its constitution, by-laws, and rules constitute a contract"4 which "define the privileges secured and the duties assumed by those who have become members" 45 and cannot be altered even by long-established custom or usage; ${ }^{46}$ at the very least they must be scrupulously followed insofar as a member's loss of union rights or privileges are concerned. ${ }^{47}$ While admittance is not judicially reviewable, ${ }^{48}$ expulsion, loss of rights, or diminution of privileges is ${ }^{49}$ and while union

${ }_{42}$ Snay v. Lovely, 276 Mass. 159, I76 N.E. 79 I (I93I); Cabana v. Holstein Ass'n, I96 App. Div. 842, I88 N.Y. Supp. 277 (4th Dep't, I921) aff'd 233 N.Y. 644, I35 N.E. 953 (I922); Andrews v. Local No. I3, Journeymen Plumbers, Gas \& Steamfitters, etc., I33 N.Y. Misc. 899,234 N.Y. Supp. 208 (S. Ct., 1929). We are not concerned with exceptions to this rule, as in a situation where a unionist is wrongfully ousted and no relief can be obtained by prosecuting an internal union appeal. See also Tesoriero v. Miller, 274 App. Div. 670,88 N.Y.S. $2 d 87$ (4th Dep't, I949), where a claim of union bad faith in expelling a member because of a trivial and unimportant infraction was upheld.

${ }^{43}$ Tisa v. Potofsky, 9o F. Supp. I75, I79 (S.D.N.Y., I950), holding expulsion of a member union by the CIO did not constitute a labor dispute within the terms of the Norris-La Guardia Act.

44 Nilan v. Colleran, 283 N.Y. 84,27 N.E. 2 d 5 II (1940); Brownfield v. Simon, I53 N.Y. Supp. 187 (S. Ct., I916).

45 Polin v. Kaplan, 257 N.Y. 277, 28I, I77 N.E. 833, 834 (193I).

$4^{6}$ Carey v. Int'l Brotherhood of Paper Makers, I23 N.Y. Misc. 680, 206 N.Y. Supp. 73 (Sup. Ct., I924).

47 Polin v. Kaplan, 257 N.Y. 277,28 r, 177 N.E. 833,834 (r93r), and cases cited and quoted. ${ }^{48}$ Simons v. Berry, 2 10 App. Div. 90, 205 N.Y. Supp. 442 (Ist Dep't, x924).

${ }^{49}$ Pratt v. Rudisule, 249 App. Div. 305, 292 N.Y. Supp. 68 (4th Dep't, r936); Koukly v. Canavan, I54 N.Y. Misc. 343 , 277 N.Y. Supp. 28 (S. Ct., 1935); Sweetman v. Barrows, 263 Mass. 349, I6I N.E. 272 (I928). 
discipline includes the power to suspend ${ }^{50}$ or even expel, ${ }^{5 x}$ such union action, especially expulsion, constitutes not alone loss of a valuable property right ${ }^{52}$ but may also be tantamount to a possible deprivation of life itself, ${ }^{53}$ thereby making arbitrary and unjustifiable union action judicially reviewable and reversible. Without statutory permission for such judicial power to be exercised, courts of equity in the past have felt that inherent judicial power existed and could be used to correct manifest injustices, thereby allowing themselves to invade a union's internal functions. But this negative action, resulting in a construction that certain union provisions or actiyities were unenforceable as against a member. forced affirmative union action towards such member who thereby gained a degree of immunity regardless of union desires. Over the years the due process clauses, both federal and state, have become engrafted onto union actions and, at times, are found procedurally set forth in constitutions.

The basic requirement has been fair play, rather than justice in the moral sense, a contrast between lex and jus. Has the individual received all contractual rights? Has he been deprived of his union constitutional privileges? Were charges regularly preferred? Did he have an opportunity to meet them at a fair hearing before an unbiased union tribunal? Has he taken all internal union appeals? Is there anything which due process, in its procedural aspects, yet holds out to him? The questions arising under judicial review are two-fold: (I) What rights and privileges did the member have according to the union constitution, by-laws, and rules? (2) Did he receive all these in a setting of due process? Then, the court asks, what more can he expect? Unions are entitled to settle their own internal quarrels $^{54}$ and determine their own questions of policy and discipline, ${ }^{55}$ and the unionist is entitled to no more than he has agreed to receive (the constitution), or that the law gives him (procedural due process). Although

50 Walsh v. Reardon, 274 Mass. 530, I74 N.E. 912 (I93I).

5x Interborough Rapid Transit Co. v. Lavin, 247 N.Y. 65, I59 N.E. 863 (1928); Sammel v. Myrup, I 2 N.Y.S. 2d 217 (N.Y. Munic. Ct., I939); Sweetman v. Barrows, 263 Mass. 349, I6I N.E. 272 ( $\left.\mathrm{Ig}_{2} 8\right)$.

52 Pratt v. Rudisule, 249 App. Div. 305, 292 N.Y. Supp. 68 (4th Dep't, r936); Strobel v. Irving, 17 I N.Y. Misc. 965 , I4 N.Y.S. 2d 864 (N.Y. Munic. Ct., I939); Barbrick v. Huddell, 245 Mass. 428, I39 N.E. 629 (I923); Hanson v. Mayers, 243 Mass. 25, I36 N.E. 82 (1922).

53 Slaughter-House Cases, $x 6$ Wall. (U.S.) 36, I27 (1873); Truax v. Raich, 239 U.S. 33 (I9r5).

54 Hendren v. Curtis, I64 N.Y. Misc. 20, 297 N.Y. Supp. 364 (S. Ct., I937); Bricklayers' Union v. Bowen, 183 N.Y. Supp. 855 (S. Ct., I920).

55 Nilan v. Colleran, 283 N.Y. 84,27 N.E. 2 d 5 II (I940); O'Keefe v. Local 463 of United Ass'n of Plumbers, 277 N.Y. 300 , 14 N.E. $2 d 77$ (1938). 
acting in a quasi-judicial sense, a union is not thereby part of the judicial machinery or subject, internally, to the substantive law of the land. Assuming good faith and proper methods, its decisions are to be treated as conclusive ${ }^{56}$ in the absence of capricious or arbitrary action..$^{57}$

The possible consequences of this broad doctrine of general judicial laissez faire abound in the reports which contain examples of bad and good union action in this field. In 1928 , in Sweetman v. Barrows, ${ }^{58}$ a conspiracy suit for damages was brought against union officials and the entire membership, alleging expulsion based upon an illegal demand for assessments which had been held unjustified in a prior court decision. The Massachusetts court properly held for plaintiff but the opinion included statements which, although plausible then, are undoubtedly in error today.

His right to follow a lawful occupation under existing conditions will be protected by the court, and, if it were essential for him to remain in the union in order to gain employment, he can recover for the wrong done him in depriving him of the means of earning a living and in illegally expelling him or refusing to recognize him as a member. He had an undoubted right to dispose of his labor to the best advantage and if the defendants or any of them conspired to deprive him of this natural right, he can recover damages for the wrong done. 59

Interpretations of similar language in an earlier period had led to the Supreme Court position expressed in Coppage v. Kansas, ${ }^{60}$ Truax v. Corrigan, ${ }^{6 x}$ Lochner v. Nerw York, ${ }^{62}$ Adair v. United States, ${ }^{63}$ and a host of others, all subsequently limited or discarded. ${ }^{64}$ These reversals display a judicial awareness that freedom in actuality is a relative term, and that the con-

${ }^{6}$ Pratt v. Rudisule, 249 App. Div. 305,292 N.Y. Supp. 68 (4th Dep't, I936). In Polin v. Kaplan, 257 N.Y. 277,281 , I77 N.E. 833,834 ( $993 \mathrm{x}$ ), the court stated that "if the contract reasonably provides that the performance of certain acts will constitute a sufficient cause for the expulsion of a member, and that charges of their performance, with notice to the member, shall be tried before a tribunal set up by the association, the provision is exclusive, and the judgment of the tribunal, rendered after a fair trial, that the member has committed the offenses charged and must be expelled, will not be reviewed by the regularly constituted courts."

57 Jurisdiction is here assumed. Bartone v. Di Pietro, I8 N.Y.S. 2d I78 (S. Ct., I939); Donovan v. Travers, 285 Mass. 167 , I88 N.E. 705 (1934); Engel v. Walsh, 258 Ill. 98 , IOI N.E. 222 (IgI3); Heasley v. Operative Plasterers, etc., Ass'n, Local No. 36, 324 Pa. 257, I88 Atl. 206 (I936).

$$
\begin{aligned}
& { }_{58}^{8} 263 \text { Mass. 349, I6I N.E. } 272 \text { (I928). } \quad{ }^{6 x} 257 \text { U.S. } 3 \text { I2 (I92I). } \\
& 59 \text { Ibid., at } 354 \text {. } \\
& { }^{60} 236 \text { U.S. I (IgI5). } \\
& 62 \text { Ig8 U.S. } 45 \text { (Ig05). } \\
& { }^{63} 208 \text { U.S. r6r (rgo8). }
\end{aligned}
$$

${ }^{6}$ Consult Phelps Dodge Corp. v. NLRB, 313 U.S. 177, 187 (I94I), wherein Justice Frankfurter says that "[t]he course of decisions in this Court since Adair v. United States... and Coppage v. Kansas ... have completely sapped those cases of their authority." See also West Coast Hotel Co. v. Parrish, 300 U.S. 379 (I937), overruling Adkins v. Children's Hospital, 26I U.S. 525 (x923). 
cept is found imperfectly in life and in production relations. The entire history of labor in this country indicates that unions have been an outgrowth of, or an answer to, employers' prior negativistic attitudes, and that as defensive mechanisms unions required governmental aid to equalize the disparity in economic strength and legal resourcefulness. Whether or not such continued aid is a necessity is a policy question, not here involved. ${ }^{65}$ Such aid, if given, may be of two forms: required employer recognition of the union, ${ }^{66}$, and some degree of freedom for the union to develop as it feels its own best interests require. ${ }^{67}$

The approach to union self-government is two-fold. Our political theories require association for the highest self-development of the individual, so that group efforts are to be fostered and furthered, and yet all

${ }_{65}$ The Wagner Act, 49 Stat. 449 (I935), reflected that era's feeling that employees and unions alone required aid, and therefore attempted to equalize the employer-employee disparity by pushing up the latter's floor to set it even with the former. The Taft-Hartley Act, 6I Stat. I36 (I947), 29 U.S.C.A. \& I4I (Supp., I950), suggests that such boost had now created the converse disparity, and that the employee had shot up and past the employer, so that the present Act attempted to equalize their positions. But, it is here queried, can there be "absolute" equality? Or does the Act speak of a "legal" equality which, based upon the outmoded fictions of the law, prevents a peek from behind the blindfold Justice wears to see the realities of the alleged equality? It is submitted that it is this latter legalistic concept which the 1947 Act promulgated, and that Senator Taft's proposed 1949 amendments were required by the inequalities thereby engendered.

As to whether the Wagner "up" required Taft-Hartley's "down," see Lazarus and Goldberg, Collective Bargaining $37 \mathrm{ff}$. (I949). As to whether or not labor still requires organization, even in the clothing industry, see N.Y. Times, p. 38 , col. 3 and p. 38 , col. 2 (Nov. 29, 1950) recording the signing of two contracts by the Amalgamated Clothing Workers with employers who, in sixteen and fifty-one years, respectively, had never had dealings with a labor organization.

${ }^{66}$ This brings up all the corollaries which are found both in the old and in the amended Wagner Act. For example, Section 7 gives us this concept of employee freedom to organize and bargain collectively through their chosen representatives, but the succeeding sections give us the methods whereby this fundamental Section 7 right is to be effectuated.

${ }^{67}$ In United States v. Hutcheson, 3 I2 U.S. 219 (I94I), criminal indictments were brought against the carpenters and union officials charging a restraint and conspiracy to restrain trade by combatting another union in a jurisdictional dispute, rather than fighting an employer; the Supreme Court dismissed, Justice Frankfurter stating that the national policy, expressed by the Clayton and Norris-La Guardia Acts, permitted workers to have "full freedom of association, self-organization" (as set forth in the latter Act). For the general rule today concerning a union's permissible actions under the anti-trust laws, see Forkosch, Equity Versus TaftHartley Injunction, 24 Temp. L.Q. 277 (I95I). These union actions, however, are external rather than the internal actions we here discuss, and the language of the Court must be limited to the field of its fact-situation. In conjunction with note 72 infra, where the union-employer activity was denounced, it was reported in N.Y. Times, p. 34, col. 2 (Dec. 2I, 1950) that the secretary-treasurer of Local $8 \mathrm{I} 6$ of the International Brotherhood of Teamsters, AFL, was accused by one employer of an alleged "dictatorship" in that he was "conspiring" with a second employer to break the former's contracts for delivery of liquor, thereby giving the second employer such deliveries and thereby a monopoly. This was vehemently denied, N.Y. Times, p. 21, col. 2 (Dec. 27, I950); the court denied a temporary injunction and vacated a stay on the ground that "no evidentiary facts are submitted to show" that any conspiracy existed. N.Y. Times, p. 24, col. 3 (Jan. Io, I95x). 
human activity, individual or collective, conflicts at times with others' like efforts and activities. Even a Robinson Crusoe was not completely alone, for he had civilization's tools and knowledge with him; so, too, is it impossible for anyone in modern life to be apart from his fellow men. It is the inevitability of possible conflict, ${ }^{68}$ and the necessity of avoiding anarchism and all that it implies, that makes necessary rules of and for the individual's behavior; whether these rules are self-promulgated by such individual or by society is presently of no moment. But enforcement, when it "should" proceed from one's own desire to follow the Golden Rule, is a moral concept, whereas the basic requirement of all legal rules necessitates an objective, coercive power. Insofar as the association promulgates and enforces its own rules which are consonant with the external power's limitations, the latter will refrain from exerting any reviewing function; insofar as such rules do conflict with the policy (statutes) or mores (equity) that a government expresses and enforces, review is accorded to the aggrieved party.

Obviously such policies or mores change; certainly yesteryear's "freedom of contract" no longer permits activities which today are denounced because their factual operation has resulted in enfeebling the individual and thereby the nation; and, finally, the trend discloses that the individual is once again being faced with the possibility that a new form of power will be exerted which, because of its effects, must itself be curbed. The probability that union conduct vis-à-vis individual members will turn into domination increases as various union practices are found to be wanting in the over-all picture, and yet are not modified or discarded. Some of these have already been discussed; others can be inferred; and still others are unknown possibilities. It is these latter which are the basis for present fears and legislation or decisions. The outstanding element of union statesmanship today would be to serve notice that expulsion or suspension, and

\footnotetext{
${ }^{68}$ Adamic, Dynamite (rev. ed., 1934), subtitled "The Story of Class Violence in American," is based upon the inevitability of class conflict in a capitalistic production and distribution society given over to an employer's primary desires for profit and assumes that continuing "bitter disputes between labor and capital and between radical or revolutionary and conservative (in many cases racketeering) labor unions" will necessarily flare up and "be accompanied by violence of an extreme character." Ibid., at ix. The volume's concluding paragraph accentuates the continuation of violence until labor groups are organized "into unions with revolutionary aims to power. Then they will be able to afford to dispense with such violence. . . ." Ibid., at 480 . With such assumption and conclusion this writer disagrees and, insofar as labor unions are concerned, points to the non-violence of numerous large and small unions which honor contracts, achieve their goals through collective bargaining, utilize persuasion at all stages, and are more desirous of stability than many an employer. Further proof of Adamic's error is found in the 1948-1950 ousting of the minority elements in most locals. See also Braun, UnionManagement Cooperation(I947); Lever and Goodell, Labor-Management Cooperation (I948).
} 
all its attendant miseries, would not be visited upon individuals save in matters of the most grievous nature, ${ }^{69}$ and that even then such union action would be the end result of procedures which themselves would be legally and morally unassailable. Present union constitutions do not particularize in these two respects in a manner sufficient to satisfy the suggestions here made.

For example, the Nazi "crimes against the state" were denounced because the judge alone, in a case before him, could decide whether the facts constituted such crime. Americans decried this as inhuman, for no man could know in advance of his conviction whether or not his actions of yesterday were a crime; he had no statutory definition to guide him. So, too, do we denounce our own statutes which are vague and uncertain, do not set up sufficient standards, or leave to someone's discretion the problem of crime or no crime. Then what of union provisions which permit charges and expulsión where a member acts "contrary to the best interests" of the local or international, or where the member has committed acts which "discredit" the union or its officers, or where the union's "policies" are ignored or not furthered? These catch-all provisions are not indicative of maturity or statesmanship and serve no purpose, propaganda or otherwise, for they are so vague that a charge of capriciousness invariably results in court review, judicial imposition of legal concepts, and thereby a possible alteration of language from its intended purpose.

Thus an over-all conclusion may be drawn ${ }^{70}$ which, based upon the past and the present, may avoid the logical pitfalls which legal reasoning involves: (I) union constitutions, by-laws, and rules should be clear and explicit in setting forth and defining grounds for expulsion and suspen-

${ }^{69}$ In Weinstock v. Ladisky, I97 N.Y. Misc. 859,87 r, 98 N.Y.S. 2 d 85,97 (S. Ct., I950), the court stated: "It should be noted that... labor unions, have inherent power, somewhat akin to the police power of a state, to provide for the welfare of their members and to regulate their affairs so as to attain the objects and purposes for which they were constituted. Aside from and independent of any provisions in its constitution and by-laws, a labor union has the right of self-protection and self-preservation, and may discipline a member or officer for conduct tending to thwart or destroy its objects. Such power may be exercised even to the extent of expelling a member from the organization."

$7^{70}$ The I943 American Civil Liberties Union Report, note 15 supra, at 68 et seq., proposed a Bill of Rights for union members, one of which sought to protect the individual from arbitrary disciplinary proceedings, and suggested that the unions accomplish these (protection) goals themselves; legislation, however, was also recommended which would require an administering agency to hear and determine questions of expulsion or suspension, with judicial review thereafter, and also similar hearings concerning rights under the union's constitution. The Report stated that "members should not be penalized or expelled for activities involving their basic democratic rights" which included criticism of union officers, the right to organize within the union in opposition to the administration, free speech concerning their opposition, and when internal information channels are closed, to voice protests outside the union. Ibid., at $28 \mathrm{ff}$. 
sion; (2) no reasons other than those disclosed by the notice of charges, and within the permissible scope of the constitution, should become the basis for any such proceedings; (3) all procedural formalities ordinarily accorded a defendant in a criminal court hearing should be observed, with legal representation permitted before an unbiased tribunal; ${ }^{7 x}(4)$ a stenographic record of the hearing should be made, if possible, or at the very least of the testimony of the most important witnesses plus a condensed version of all other testimony; (5) opportunity for some form of eventual appeal to the entire membership, with approval required for expulsion or suspension.

Under these conditions no court would find that due process, procedurally and substantively, had not been accorded. When the courts thus legally refrain from interfering, labor will be actually free to guide and govern itself and this, it is submitted, is a wise policy. ${ }^{7^{2}}$ It is the concept of individual, association, and employer and employee self-rule (through real collective bargaining) that is the goal which is frustrated by governmental restrictions. ${ }^{73}$ Restrictions should not be haphazardly imposed on all unions as long as the small percentage of abuses which do occur may conceivably be disposed of by existing laws. Only as a final "must" should the freedom of unions, as with the freedom of individuals and all groups, be circumscribed.

\footnotetext{
$7 x$ Perhaps an outside body may be asked to sit, or one or more outsiders asked to join the union tribunal. In any event, it is the actuality of fairness, rather than its appearance, which should govern.

${ }^{72} \mathrm{~A}$ recent instance illustrates this forcefully. In Allen Bradley Co. v. Local 3, IBEW, 325 U.S. 797 (1945), the Supreme Court held that a union ran afoul the Sherman Act when it collaborated with (or instigated) employers and their associations in excluding from the New York market manufactured electrical products which competed with locally produced ones. The decision, however, permitted union conduct "on its own," even though such "lone wolf" conduct resulted in identical ends being obtained. Union self-discipline was shown when the I.B.E.W. thereafter found Local 3 's veteran business agent guilty of discriminatorily practicing exclusion from the New York market of electrical products made by unions elsewhere in the country, conducting its own hearings, etc., by a reference to an outsider. Consult N.Y. Times, p. 23 , col. 2 (June 26, 1950).

73 Thus a contrast between the Wagner "voluntarism"and the Taft-Hartley "restrictionism" is presented which displays in brief the fundamental public (not alone union) objection to the over-all policy of the latter Act.
} 